\title{
Has Latour Real-ly Unravelled the Real: The Unrivalled Journey from Laboratory Life to Down to Earth?
}

\author{
Charles Lawson \\ Griffith University, Australia
}

\begin{abstract}
This article traces Bruno Latour's answer to the question 'what is real?' from Latour and Steve Woolgar in Laboratory Life: The Social Construction of Scientific Facts (1979) through to Latour in Down to Earth: Politics in the New Climate Change (2018). This intriguing question arises because Latour's hypothesis in Down to Earth presumes that climate change is 'real', while in Laboratory Life, hard facts were considered constructions. The journey reveals Latour's own 'real' lies between the extreme science realists (facts are either true or false) and extreme social relativists (facts are a social construction), although favouring the relativists. A closer analysis, however, shows that Latour's project is really about truth claims and that the real question is couched in terms rejecting the modernist settlement of ontological assumptions and basing truth on credibility determined by the strength of associations; the more associations, the more 'real' the truth claim. Ultimately, Latour elegantly sidesteps the real question and how he does this is real-ly unrivalled.
\end{abstract}

Keywords: Bruno Latour; Laboratory Life; Down to Earth; real; truth; facts; construction of facts.

\section{Introduction}

During 1979, in Laboratory Life: The Social Construction of Scientific Facts (Laboratory Life), Latour and Woolgar entranced us with the insight that inscribing facts ${ }^{1}$ was actually something constructed-'hard facts are thoroughly understandable in terms of their social construction': ${ }^{2}$

\begin{abstract}
By contrast, we do not conceive of scientists using various strategies as pulling back a curtain on pre-given, but hitherto concealed, truths. Rather, objects ... are constituted through the artful creativity of scientists ... We have therefore found it extremely difficult to formulate descriptions of scientific activity which do not yield to the misleading impression that science is about discovery (rather than creativity and construction). ${ }^{3}$
\end{abstract}

Then in 2018, in Down to Earth: Politics in the New Climate Change (Down to Earth), Latour tackles the three phenomena he calls 'deregulation', 'inequalities' and the 'systematic effort to deny the existence of climate change. '4 He then says, assuming that climate change is real ('more and more indisputable') ${ }^{5}$ and decrying the claims and consequences of climate change deniers:

I acknowledge and appreciate the discussions, assistance, guidance and suggestions form Michelle Rourke, Kieran Tranter and Edwin Bikundo grappling with this issue and finally bringing the ideas to a text. I am also grateful to the referees for their insightful comments, suggestions and encouragement.

${ }^{1}$ Latour and Woolgar, Laboratory Life (1986), 76.

${ }^{2}$ Latour and Woolgar, Laboratory Life (1986), 107.

${ }^{3}$ Latour and Woolgar, Laboratory Life (1986), 129.

${ }^{4}$ Latour, Down to Earth, 1.

${ }^{5}$ Latour, Down to Earth, 18.

Except where otherwise noted, content in this journal is licensed under a Creative Commons Attribution 4.0 International Licence. As an open access journal, articles are free to use with proper attribution. ISSN: 2652-4074 (Online) 
The hypothesis is that we can understand nothing about the politics of the last 50 years if we do not put the question of climate change and its denial front and centre. Without the idea that we have entered the New Climate Regime, we cannot understand the explosion of inequalities, the scope of deregulation, the critique of globalisation, or, most importantly, the panicky desire to return to the old protections of the nation-state [endnotes omitted]. ${ }^{6}$

This article asks: what does Latour in 2018 in Down to Earth now think about his conception in 1979 in Laboratory Life of the 'objects' that 'are constituted through the artful creativity of scientists'? ${ }^{7}$ This intriguing question arises because Latour's hypothesis in Down to Earth presumes that climate change is 'real', and not just a construction of 'the militancy of millions of ecologists, the warnings of thousands of scientists, the actions of hundreds of industrialists. ${ }^{8}$ The challenge in writing this article, therefore, is to reconcile the Latour in Laboratory Life and the Latour in Down to Earth. The following parts very briefly outline some of the key texts in Latour's journey between Laboratory Life and Down to Earth that introduce and then refine the 'real' question and answer. This eventually shows that Latour has remained loyal to Laboratory Life as a description of science as it is practised from the lens of an anthropologist (sociologist). Importantly, however, Latour's 'real' as it stands today is not as extreme as that presented in Laboratory Life but is still very much constructed (or fabricated) and framed very differently from the views of positivist, realist scientists. The article quotes Latour extensively in his own words to show how Latour's use of artful language (including metaphors ${ }^{9}$ and diagrams) ${ }^{10}$ often obfuscates his arguments so that criticism can be deflected by multiple and uncertain meanings ${ }^{11}$ or even creatively misunderstood..$^{12}$ This will enable the reader to adjudicate my exegesis 'through a very dense discursive jungle, packed with polemical claims, metaphors, empirical data and philosophical arguments. ${ }^{13}$ The article concludes that Latour and his anthropology/sociology/philosophy of science are a part of the larger project about truth claims, and as such, the reality of climate change in Down to Earth was not about the 'real' as opposed to Latour accepting the truth claim that climate change $i s$ real.

\section{Laboratory Life Starts the Journey}

Latour started his academic employment in the early 1970s, in the recently post-colonial Republic of Côte d'Ivoire, puzzled by why the ideas of modernity contrasted the modern and premodern, and yet the Moderns did not apply the same investigative methods to themselves. ${ }^{14}$ From this experience, Latour set out to apply the methods of the social sciences, like anthropology and ethnography, to modern practices. Laboratory Life, with Woolgar, was the outcome. At the time, they were trying to understand 'how a fact takes on a quality which appears to place it beyond the scope of some kinds of social and historical explanation. ${ }^{15}$ Later, Latour recalls this as 'an anthropology that would provide an ethnographically based description of those who call themselves rational and modern. ${ }^{16}$

The contribution of Laboratory Life was to meticulously reveal that the signs and symbols in making science and their use and interpretation were indifferent to the professed realism of the subjects and the social actors. Put simply, Laboratory Life records that scientific facts are presented without their sociality and historicity. However, it was never an attempt to develop an alternative epistemology. What Laboratory Life does is reveal that:

\footnotetext{
${ }^{6}$ Latour, Down to Earth, 2.

${ }^{7}$ Latour and Woolgar, Laboratory Life (1986), 129.

${ }^{8}$ Latour, Down to Earth, 3.

${ }^{9}$ Turner cautions:
}

'Indeed, the analytical shortcomings of Latour's handling of metaphor, and the more extreme claims about human and non-human objects - is it a daring move or just silliness to attribute agency to the sheep walking along the Champs-Élysées in a protest by French farmers? - can be taken with a pinch of salt when reading the empirical investigations, where the material-the scientists and their equipment, the lawyers and their files, the engineers and their trains, all of them and their meetings-is itself a source of intellectual discipline' (Turner, "Travels Without a Donkey," 127).

10 Turner notes:

'It may also strike the reader as ironic that a writer [Latour] who has sought to grant agency to non-human objects should treat devices such as metaphors and diagrams as passive instruments that will bend to his theoretical will rather than as tools that, owing to their own logic if not their own agency, can only make certain things imaginable' (Turner, "Travels Without a Donkey," 136).

${ }^{11}$ Bloor, for example, asks:

"What are we to make of his own "entelechies", "monads" and "actants" which are neither in nature or society, nor in language (p. 124)? All requests for clarification of this extraordinary and ill-conceived metaphysical exercise have been met by silence' (Bloor, "Reply to Bruno Latour," 134).

${ }^{12}$ Bloor, for example, critiquing Latour's critiquing of Bloor's 'causality' says:

'But I am afraid that, by this stage, I do not understand what he is trying to say' (Bloor, "Reply to Bruno Latour," 135).

${ }^{13}$ Thank you to the anonymous referee for this insight.

${ }^{14}$ Latour, "Biography of an Investigation," 289.

${ }^{15}$ Latour and Woolgar, Laboratory Life (1986), 105.

${ }^{16}$ Latour, "Biography of an Investigation," 290. 
[T] he value and status of any text (construction, fact, claim, story, this account) depend on more than its supposedly 'inherent' qualities ... the degree of accuracy (or fiction) of an account depends on what is subsequently made of the story, not on the story itself. This is the fundamental principle we showed to be at work in the modalising and demodalising of statements. Laboratory Life is once again in the hands of its readers, exactly like [thyrotropin-releasing factor (TRF)], [thyrotropinreleasing hormone], somatostatin and the other fact(or)s we discussed. It is others who transform the status of these claims, making them more or less factual, dismembering them, incorporating them into black boxes for different argumentative purposes, ridiculing them and so on. There is neither self-contradiction nor self-defeat in recognising this common destiny of all claims. On the contrary, once the common fate of claims is recognised, it becomes easier to understand the differences in predicting each reader's behaviour. Each text, laboratory, author and discipline strives to establish a world in which its own interpretations is made more likely by virtue of the increasing number of people from whom it extracts compliance. In other words, interpretations do not so much inform as perform. From this perspective, our scientists are obviously better equipped at performing the world we live in than we are at deconstructing it. The recognition of this vast difference is in no way selfdefeating. It merely acknowledges the present balance of forces. How much further research, investment, redefinition of the field, and transformation of what counts as an acceptable argument are necessary to make this account more plausible than its alternatives? ? $^{17}$

Laboratory Life detailed the processes through which a statement is metamorphosed and becomes a fact through the practice of scientists doing science. ${ }^{18}$ This does not assume there was some reality 'merely waiting to be discovered and that it finally became visible. ${ }^{19}$ Rather:

Facts and artefacts do not correspond respectively to true and false statements. Rather, statements lie along a continuum according to the extent to which they refer to the conditions of their construction. Up to a certain point on this continuum, the inclusion of reference to the conditions of construction is necessary for the purposes of persuasion. Beyond this point, the conditions of construction are either irrelevant or their inclusion can be seen as an attempt to undermine the established factlike status of the statement. Our argument is not that facts are not real, nor that they are merely artificial. Our argument is not just that facts are socially constructed. We also wish to show that the process of construction involves the uses of certain devices whereby all traces of production are made extremely difficult to detect ... From their initial inception, members of the laboratory are unable to determine whether statements are true or false, objective or subjective, highly likely or quite probable. While the agnostic process is raging, modalities are constantly added, dropped, inverted, or modified. Once the statement begins to stabilise, however, an important change takes place ... At the onset of stabilisation, the object was the virtual image of the statement; subsequently, the statement becomes the mirror image of the reality 'out there' ... It is small wonder that the statements appear to match external entities so exactly: they are the same thing. ${ }^{20}$

Putting this another way, Latour and Woolgar were asserting that 'reality' does not explain why a statement becomes a fact (cause). Instead, it is the stabilisation of the statement that forms the 'reality' (consequence) - 'reality is formed as a consequence of this stabilisation. ${ }^{21}$ The task of the anthropologists (and sociologists) like Latour and Woolgar is in understanding how these debates are resolved among scientists; the 'reality' does not account for why the statements become facts (or stabilise) because 'it is only after it becomes a fact that the effect of reality is obtained.'22 This 'reality' then extends beyond the laboratory 'to other areas of social reality, such as hospitals and industry':23

[W] hen an observer considers that the structure of TRF is Pro-Glu-His-Pro- $\mathrm{NH}_{2}$ and then realises that the 'real' TRF is also Pro-Glu-His-Pro- $\mathrm{NH}_{2}$, he marvels at this magnificent example of correspondence between man's mind and nature. But closer inspection of the process of production reveals this correspondence to be much more earthy and less mysterious: the thing and the statement correspond for the simple reason that they come from the same source. Their separation in only the final stage in the process of their construction ... many scientists and non-scientists alike, marvel at the efficacy of a scientific fact outside science. How extraordinary that a peptidic structure discovered in California works in the smallest hospital in Saudi Arabia! For one thing, it only works in well-equipped laboratories. Considering that the same set of operations produces the same answers, there is little to marvel at ... if you carry out the same assay you will produce the same object [references omitted]. ${ }^{24}$

\footnotetext{
${ }^{17}$ Latour and Woolgar, Laboratory Life (1986), 284-285.

${ }^{18}$ Latour and Woolgar, Laboratory Life (1986), 129, 175.

${ }^{19}$ Latour and Woolgar, Laboratory Life (1986), 176.

${ }^{20}$ Latour and Woolgar, Laboratory Life (1986), 176-177.

${ }^{21}$ Latour and Woolgar, Laboratory Life (1986), 180.

${ }^{22}$ Latour and Woolgar, Laboratory Life (1986), 180.

${ }^{23}$ Latour and Woolgar, Laboratory Life (1986), 182.

${ }^{24}$ Latour and Woolgar, Laboratory Life (1986), 183.
} 
After Laboratory Life, Latour developed his engagement with reality in The Pasteurization of France, ${ }^{25}$ Science in Action ${ }^{26}$ and We Have Never Been Modern. ${ }^{27}$ It was, however, the Science Wars that started soon after Laboratory Life's publication that focused on the 'reality' question. ${ }^{28}$ This was essentially the scientists (realists-facts exist out there independent of human thought) versus the humanities (relativists - all knowledge is human knowledge based in human thought) in the mode of C.P. Snow's two cultures, ${ }^{29}$ with the scientists accusing the humanities (including social scientists, cultural theorists, anthropologists, feminist theorists, science and technology studies and media studies) of rejecting scientific knowledge as real and emphasising the social and political in the construction (or fabrication) of science. ${ }^{30}$ This was, perhaps, not surprising since the traditional sociology of science was examining institutionalised forms of science as a phenomenon of society looking to the empirical practices of science using the methods of sociology. ${ }^{31}$ Just before Laboratory Life, Thomas Kuhn (in The Structure of Scientific Revolutions) had argued that cultural and socio-political paradigms among scientists founded scientific truths that were eventually overturned by new cultural and socio-political paradigms in 'scientific revolutions. ${ }^{32}$ Then, Paul Feyerabend (in Against Method) argued that scientific methodology was a guise for legitimising truth claims and that they were no better than any other methodologies for constructing knowledge, hence 'anything goes. ${ }^{33}$ Michel Foucault (in Discipline and Punish) was asserting that truth was based in power and coercion, ${ }^{34}$ Jean François Lyotard (in The Postmodern Condition) was framing scientific knowledge as a bygone and discredited meta-narrative (or grand narrative) replaced by personal perspective and story, ${ }^{35}$ Julia Kristeva (in Horror: An Essay on Abjection) was claiming that in 'being' the maternal and the feminine must be excluded, ${ }^{36}$ and so many more. The realist scientists' concerns, perhaps representative in Paul Gross and Norman Levitt's Higher Superstition: The Academic Left and Its Quarrels with Science, were that 'Scientific questions are decided and scientific controversies resolved in accord with the ideology that controls the society wherein the science is done. Social and political interest dictate scientific "answers" ... [and that] leaves no ground whatsoever for distinguishing reliable knowledge from superstition. ${ }^{37}$ The banner example of this relativism was, among many examples documented by Alan Sokal and Jean Bricmont in Intellectual Imposters, the claim that the celebrated equation $\mathrm{E}=\mathrm{mc}^{2}$ was sexed ('une equation masculine') ${ }^{38}$ because it 'privileges the speed of light over other speeds' and was, therefore, masculinely 'privileging what goes faster. ${ }^{39}$ The criticism of these influences on the science subjects researched and the science theories put forward was accepted as worthy of study, but it was that the reality of the speed of light ('c') was subject to such social influences as gender that was anathema to realist scientists. ${ }^{40}$ While this may have been an extreme example, it captures the poles between science and society.

This same Sokal and Bricmont criticism was applied to Latour's work addressing a relativistic account of Einstein's relativity. ${ }^{41}$ After detailing Latour's misunderstanding of basic physics concepts, Sokal and Bricmont assert that Latour 'confuses the pedagogy of relativity with the "technical content" of the theory itself", which does not show, as Latour had asserted, that "relativity theory is itself "social through and through". ${ }^{42}$ Their primary critique was that Latour's 'analysis is fatally flawed by his inadequate understanding of the theory Einstein is trying to explain. ${ }^{43}$ Sokal and Bricmont then use a postscript to address the request for a more sympathetic sociological reading of Latour because Latour is looking to what social scientists can learn about society and physicists can learn about their assumptions. ${ }^{44}$ This they reject because Latour expressly seeks to determine 'in what ways can we ... see Einstein's work as explicitly social' and 'how can we learn from Einstein how to study

\footnotetext{
${ }^{25}$ Latour, The Pasteurization of France.

${ }^{26}$ Latour, Science in Action.

${ }^{27}$ Latour, We Have Never Been Modern.

${ }^{28}$ See Lynch, "Social Constructivism in Science and Technology Studies," 106-110.

${ }^{29}$ Snow, The Two Cultures, 3.

${ }^{30}$ See Segerstråle, "Science and Science Studies: Enemies or Allies," 1-40. For examples of some of the key contributions, see Brown, Who Rules in Science; Hacking and Hacking, The Social Construction of What; Sokal and Bricmont, Fashionable Nonsense; Gieryn, The Cultural Boundaries of Science; Smith, Belief and Resistance; Gross, Higher Superstition. See also more recent reflective assessments: Otto, The War on Science; Labinger, The One Culture.

${ }^{31}$ See Merton, The Sociology of Science.

${ }^{32}$ Kuhn, The Structure of Scientific Revolutions.

${ }^{33}$ Feyerabend, Against Method.

${ }^{34}$ Foucault, Discipline and Punish.

${ }^{35}$ Lyotard, The Postmodern Condition.

${ }^{36}$ Kristeva, Horror.

${ }^{37}$ Gross and Levitt, Higher Superstition, 45-46.

${ }^{38}$ Irigaray, "Sujet de la Science, Sujet Sexue?," 109.

${ }^{39}$ Sokal and Bricmont, Intellectual Imposters, 100 quoting Irigaray, "Sujet de la Science, Sujet Sexue?," 110.

${ }^{40}$ Sokal and Bricmont, Intellectual Imposters, 100. See also Walsh, Science Wars, 31; Wheen, How Mumbo-Jumbo Conquered the World, 85.

${ }^{41}$ Sokal and Bricmont, Intellectual Imposters, 115-123 addressing Latour, "A Relativistic Account of Einstein's Relativity."

${ }^{42}$ Sokal and Bricmont, Intellectual Imposters, 120.

${ }^{43}$ Sokal and Bricmont, Intellectual Imposters, 121.

${ }^{44}$ Sokal and Bricmont, Intellectual Imposters, 121-122 quoting Mermin, "What's Wrong with This Reading."
} 
society?' 45 Sokal and Bricmont say there are no implications for sociology from physics, and if there was, then 'at best' they would be an analogy and would have limited value because few sociologists know much about relativity-'Why does not Latour explain whatever new sociological notions he wants to introduce by making direct reference to his readers' sociological background?'46

Importantly, for this analysis, Latour and Woolgar's Laboratory Life was a key source of authority for the argument that scientific knowledge derived from experiments was contingent and open to social construction (relativistic). ${ }^{47}$ For example:

[T] he sociology of scientific knowledge do[es] engage in the epistemological project ... they assess the totality of scientific beliefs as claims to knowledge of an objective world, and find them to have no greater (but also no less) justification than any other collectively accepted systems of belief. The new sociology has not abandoned justification; rather, it has engaged in the quite general epistemological project of showing why standard philosophical defenses of the rationality or truth of scientific claims should instead be regarded as ex post facto rationalizations. In Latour and Woolgar's words, "reality" cannot be used to explain why a statement becomes a fact, since it is only after it has become a fact that the effect of reality is obtained." 48

Further:

Latour and Woolgar ... distinguishing sociological from metaphysical anti-realism: "we do not wish to say that facts do not exist or that there is no such thing as reality ... Our point is that "out-there-ness" is the consequence of scientific work rather than its cause' (.. N.B. the [double] quotation marks ['out-there-ness'], indicating that the supposed consequence of scientific work is not reality itself, but the effect of reality, i.e., what can count as reality for social beings like us). ${ }^{49}$

Latour was conspicuously silent during these Science Wars skirmishes ${ }^{50}$ until his eventual response arrived ('was born') ${ }^{51}$ in Pandora's Hope: Essays on the Reality of Science Studies (Pandora's Hope). ${ }^{52}$ Pandora's Hope rehearsed many of the key points from Laboratory Life, The Pasteurization of France, Science in Action and We Have Never Been Modern. Nevertheless, the next part addresses Latour's ideas in Pandora's Hope in detail because they are Latour's specific response to the Science Wars ${ }^{53}$ and understanding Latour's manoeuvres requires engagement with the fine details.

\section{Pandora's Hope and What Latour Means?}

Pandora's Hope starts with Latour assuring us that he does believe in reality in relating a strange exchange with a psychologist at an international meeting. ${ }^{54}$ In the exchange, the 'highly respected psychologist' asks Latour, 'Do you believe in reality?', to which Latour says, 'But of course ... Is reality something you have to believe in?' ${ }^{55}$ Latour then explains his concern at being suspected of being a 'monster' and the 'strangeness' of the question portraying Latour as with the enemies of science aligned

${ }^{45}$ Sokal and Bricmont, Intellectual Imposters, 122.

${ }^{46}$ Sokal and Bricmont, Intellectual Imposters, 122-123.

47 Although Latour professes otherwise:

"Although we were the first to describe the materiality of the sciences with precision at long last, I suddenly found myself accused of an apparently abominable crime, committed inadvertently: calling scientific objectivity into question through "relativism" (Latour, "Biography of an Inquiry," 292).

${ }^{48}$ Rouse, "Feminism and the Social Construction of Scientific Knowledge," 201 citing Latour and Woolgar, Laboratory Life (1986), 180.

${ }^{49}$ Rouse, "Feminism and the Social Construction of Scientific Knowledge," 201 citing Latour and Woolgar, Laboratory Life (1986), 180182.

${ }^{50}$ As he revels in Pandora's Hope:

'I have not answered the science warriors' arguments term for term or even cited their names - it is because the science warriors too often waste their time attacking someone who has the same name as mine, who is said to defend all the absurdities I have disputed for twenty five years: that science is socially constructed; that all is discourse; that there is no reality out there; that everything goes; that science has no conceptual content; that the more ignorant one is the better; that everything is political anyway; that subjectivity should be mingled with objectivity; that the mightiest, manliest, and hairiest scientist always wins provided he has enough "allies" in high places; and such nonsense. I don't have to come to the rescue of that homonym!' (Latour, Pandora's Hope, 299-300).

${ }^{51}$ Latour, Pandora's Hope, 3.

${ }^{52}$ See Latour, Pandora's Hope, 300.

${ }^{53}$ Noting, of course, that Latour himself accepts that his views have changed over time:

'I would be at great pains to say which paper, chapter or book is representative of my position. I would be tempted to say that the only sources to quote and to dispute are the articles or books I am presently working on' (Latour, "For David Bloor ... and Beyond," 115).

${ }^{54}$ Latour, Pandora's Hope, 1. Notably, Latour repeats this stylistic manoeuvre in another book where he addresses a question to a scientist (a professor of climatology) from a group of industrialists:

'But why should we believe you, any more than the others?' Surprisingly, the scientist acknowledges Latour was correct and that it is the 'trust in institution of science' that confers reality rather than the specific certainty or 'high agency' (in other words, the fact rather than belief, "Science with a capital S") (Latour, An Inquiry into Modes of Existence, 2-4).

${ }^{55}$ Latour, Pandora's Hope, 1, 2 
with the constructivist (being the 'extravagant' constructivism started by Kant) 56 'militants, activists, sociologists, philosophers and technophobes of all hues. ${ }^{57}$ Latour proclaims he is on the side of the scientists "precisely because of our interest in the inner workings of scientific facts. ${ }^{58}$ Latour then learns from this encounter: "What I would call "adding realism to science" was actually seen by the scientists ... as a threat to the calling of science, as a way of decreasing its stake in truth and their claims to certainty. ${ }^{59}$ Pandora's Hope then sets out to retrace Latour's steps in addressing the question, 'Do you believe in reality?'60

After this introduction, Latour details a field trip to the Amazon with scientists to investigate the boundary between the forest and the savanna. ${ }^{61}$ The question the scientists were addressing was whether the forest was advancing into the savanna or the savanna was advancing into the forest. This was a complicated question and could not be answered just by looking at the plants and other readily observable characters. A scientific investigation was necessary with the hypothesis that savannas have sandy soils and forests have clay soils, and clay can degrade to sand, but sand cannot reconstitute to clay ${ }^{62}$ - is it 'sandy clay' or 'clayey sand'? ${ }^{63}$ His purpose was to debunk the 'old settlement' that there was a 'gap between words and the world' that was bridged with the Kantian ideal of correspondence ('the Königsberg broadcast'), ${ }^{64}$ and instead 'show that there is neither correspondence, nor gaps, nor even two distinct ontological domains', but instead what he calls 'circulating references' (or 'the chain of transformations') ${ }^{65}$

In doing their science, the scientists collected soil samples along a transect from the savanna to the forest. ${ }^{66}$ This collection is the moment where the soil becomes a sign and gains a geometric form and a number through the process of inscription by the scientists. ${ }^{67}$ This is the moment of transformation when a clump of earth becomes a sign. It continues the process of transformation when transported to the laboratory, where the samples are colour coded and arranged so that the different soil colours are apparent, arrayed to form a chart that eventually translates the forest/savanna transition into something understandable, and is then presented as a figure in a scientific article. ${ }^{68}$

For Latour, this expedition to the forest reveals the 'impossibility' of 'the original model of philosophers language' (presumably the Kantian correspondence between the world and language across the gap that he terms the 'canonical view') because what he has done is to 'obliterate, bit by bit' the 'longing for correspondence' with each of the 'mediations' between the savanna and the forest: ${ }^{69}$

\begin{abstract}
We never detect the rupture between things and signs, and we never face the imposition of arbitrary and discrete signs on shapeless and continuous matter. We see only an unbroken series of well-nested elements, each of which plays the role of sign for the previous one and of thing for the succeeding one..$^{70}$
\end{abstract}

Latour then concludes from this detailed documenting of the field trip to the Amazon that the scientists use successive stages to align, transform and construct the world..$^{71} \mathrm{He}$ rhetorically says:

\footnotetext{
${ }^{56}$ Latour, Pandora's Hope, 5.

${ }^{57}$ Latour, Pandora's Hope, 2, 3.

${ }^{58}$ Latour, Pandora's Hope, 3.

${ }^{59}$ Latour, Pandora's Hope, 3.

${ }^{60}$ Latour, Pandora's Hope, 3.

${ }^{61}$ Latour, Pandora's Hope, 24-79.

${ }^{62}$ Latour, Pandora's Hope, 26-27.

${ }^{63}$ Latour, Pandora's Hope, 63.

${ }^{64}$ Latour, Pandora's Hope, 5.

${ }^{65}$ Latour, Pandora's Hope, 24, 310. In the obfuscating technique Latour favours and masterfully displayed in this text he invents a phrase like 'circulating reference' (p. 24) that he then defines, in this case in a bibliography as 'CIRCULATING REFERENCE: See reference' (p. 304) where 'REFERENCE, REFERENT' means: 'Terms from linguistics and philosophy that are used to define ... "Reference" does not designate an external referent that will be meaningless (that is, literally without means to achieve its movements), but the quality of the chain of transformations, the viability of its circulation' (p. 310). Through the body of the book he then moves casually between the terminology 'circulating reference' and 'transformation' and then joins this terminology to other artful words like: 'Through successive stages they link us to an aligned, transformed, constructed world' (p. 79). Does 'constructed' actually mean 'circulating reference'?

${ }^{66}$ Latour, Pandora's Hope, 42-51.

${ }^{67}$ Latour, Pandora's Hope, 51.

${ }^{68}$ Latour, Pandora's Hope, 51-57. See also Latour, “The 'Pédolil' of Boa Vista: A Photo-Philosophical Montage."

${ }^{69}$ Latour, Pandora's Hope, 72-73.

${ }^{70}$ Latour, Pandora's Hope, 56.

${ }^{71}$ Latour, Pandora's Hope, 79.
} 
I can never verify the resemblances between my mind and the world, but I can, if I pay the price, extend the chain of transformations wherever verified reference circulates through constant substitutions. Is this 'deambulatory' philosophy of science not more realist, and certainly more realistic, than the old settlement? ${ }^{72}$

Now, because we are talking science studies here and not science per se, Latour also insists that we consider the broader context. He rejects as misunderstandings the claims that he is engaging, first, a 'social explanation' of scientific facts, and secondly, a rhetoric and discourse that does not care about the real world. ${ }^{73} \mathrm{He}$ then points to the story of Frédéric Joliot bringing nuclear fission to France (in the guise of neutrons, deuterium and absorption coefficients of paraffin) and the backstory of intrigues with, for example, the phony wars, nationalism, spies, in the way that this happened. ${ }^{74} \mathrm{He}$ says:

Science studies, to be sure, rejects the idea of a science disconnected from the rest of society, but this rejection does not mean that it embraces the opposite position, that of a 'social construction' of reality or that it ends up in some intermediary position, trying to sort out 'purely' scientific factors from 'merely' social ones ... What science studies rejects is the entire research program that would try to divide the story of Joliot into two parts: one from the legal problems ..., the 'phony war', ... nationalism, the German spies, and the other for neutrons, deuterium and absorption coefficients of paraffin. ${ }^{75}$

Latour appears to be saying that to understand this real world, you need to consider some of these other factors. That is, without alliances, colleagues, instruments, there would be no facts to be persuasive:

\begin{abstract}
The project of science studies, contrary to what the science warriors have tried to make everyone believe, is not to state a priori that there exists 'some connection' between science and society because the existence of this connection depends on what the actors have done or not done to establish it. Science studies merely provides the means of tracing this connection when it exists. Instead of cutting the Gordian knot—on the one hand pure science, on the other pure politics-it struggles to follow the gestures of those who tie it tighter. The actual history of sciences does not say: 'look for society hidden in, behind, or underneath the sciences.' It merely asks some simple questions: 'In a given period, how long can you follow a policy before having to deal with the detailed content of a science? How long can you examine the reasoning of a scientist before having to get involved with the details of the policy? A minute? A century? An eternity? A second? All we ask of you is not to cut away the thread when it leads you, through a series of imperceptible transitions, from one type of element to another.' All the answers are interesting and count as major data for anyone who wishes to understand this imbroglio of things and people-including, of course, the data that might show that there is not the slightest connection, at a given time, between a piece of science and the rest of the culture. ${ }^{76}$
\end{abstract}

Put slightly differently, his account is neither merely extending the social explanations to science and technology nor confirming that reality exists out there. Latour's point is that by understanding the transformations of the science facts, including the broader context, there is a gain in realism 'of scientific facts' and, using his words, 'science gains in hardness. ${ }^{77}$ His illustration of this is the development of a nuclear industry in France where Joliot, the French atomic physicist, was keen to test his ideas that there were excess neutrons that could be released and harnessed through a chain reaction. ${ }^{78}$ This required access to things like heavy water, financial resources and laboratories all held together as a 'complex web of connections. ${ }^{.79}$ Latour's point is that without all these other factors, there would have been no experiment and that these other factors are a part of the construction of the facts. It is the coming together of these human and non-human factors in the conceptual elements-instruments, colleagues, allies, public representations and links and knots- that you get the circulating scientific facts. ${ }^{80}$ Most importantly, science studies is something distinctly different from just social explanation and scientific facts because it is about the transformations:

[S]cience studies sees a slow, continuous, and entirely explicable substitution of a certain kind of concern and a certain kind of practice for another ... What matters for science studies is that a heterogeneous assembly of hitherto unrelated elements now shares a common fate within a common collective, and that Joliot's words will become true or false according to what circulates throughout this entire newly assembled collective. It is too late to claim that ontological and epistemological questions should

\footnotetext{
${ }^{72}$ Latour, Pandora's Hope, 79.

${ }^{73}$ Latour, Pandora's Hope, 84. Perhaps Latour's most compelling defence of his project was to point out that he was not trying to explain the 'hard facts' of science compared with the 'soft facts' of social science, and uncovering society or nature, but rather his project is 'to understand how science and technology were providing some of the ingredients necessary to account for the very making and the very stability of society' (Latour, "The Promises of Constructivism," 30 ).

${ }^{74}$ Latour, Pandora's Hope, 81-84.

${ }^{75}$ Latour, Pandora's Hope, 84.

${ }^{76}$ Latour, Pandora's Hope, 86-87.

${ }^{77}$ Latour, Pandora's Hope, 109.

${ }^{78}$ Latour, Pandora's Hope, 84-86.

${ }^{79}$ Latour, Pandora's Hope, 90.

${ }^{80}$ Latour, Pandora's Hope, 88-92, 98-108.
} 
be kept neatly distinct. Because of Joliot's work these questions are now tied to one another, and the relevance of what he says to what the world is really like now hinges on [the hypothesised release of neutrons]. ${ }^{81}$

Essentially, Latour's manoeuvre is to point out that the question, 'Do you believe in reality?', presupposes a distinction between 'real' and 'social' that does not actually exist in practice. His third way is that science is a process in which non-human things are transformed from one kind of reality to another, and the kind of reality from doing science is socialising things so that they can be adapted to the collectives of humans and non-humans that already exist. ${ }^{82}$ Using Latour's words, scientists practising science 'Through successive stages [link] us to an aligned, transformed, constructed world. ${ }^{83}$ In this Latour-world, there is always a collective of humans and non-humans operating together in various ways that link these 'facts' to the broader 'society. ${ }^{, 84}$ This gets around the problem of there being a world 'out there' and a 'mind-in-a-vat' seeking a correspondence between worlds and the words for some semblance of reality, and instead finds the 'sturdy and thick layering of transverse paths' of circulating transformations. ${ }^{85}$ The language of science studies for this is 'construction' and 'fabrication'-for example, the 'construction of facts' or the 'fabrication of neutrons. ${ }^{86}$

As Latour notes, these expressions of 'construction' and 'fabrication' 'throw science warriors into fits ... which they now fling back at us. ${ }^{87}$ For Latour, this is just a misunderstanding and these terms needed to be 'reconfigured totally. ${ }^{98}$ Latour's vehicle for this was Louis Pasteur's experiment showing that yeast ferments sugar ${ }^{89}$ illustrating how the facts are 'constructed' and 'fabricated' through experiment-how a new entity can emerge out of the old.$^{90}$ For Latour, this is best illustrated by Pasteur's experiments revealing the 'fabrication' of the 'constructed' fact in three inseparable parts: ${ }^{91}$

1. The story - at this stage, there is only fairy tale or myth that something is different. For Pasteur, this myth was that the then accepted account of fermentation as a complex chemical reaction separate from yeast was wrong because Pasteur speculated (the fairy tale or myth) that yeast was the active element for fermentation.

2. The staging - this involves the laboratory with its glassware, yeasts and laboratory assistants. These are the non-verbal and nonlinguistic components of the experiment.

3. The trial - the (artificial) experiment must deliver results that are then inscribed as facts, where the trial appears to happen without the cleverness of Pasteur inventing the trial or Pasteur's competence in conducting the trial.

The experiment here is, and this is central to understanding Latour's perspective, the experimenter (Pasteur) 'designing devious plots and careful staging that makes the actant [defined by Latour as the human and non-human actors] ${ }^{92}$ participate in new and unexpected situations that will actively define it' with the fact that emerges from the successful experiment as a statement. ${ }^{93}$ This means that 'The accuracy of the statement is not related to a state of affairs out there, but to the traceability of a series of transformations." 94 The effect of the experiment is that Pasteur and the ferment "mutually exchange and enhance their properties', and, importantly, 'the lactic acid ferment is invented not by Pasteur but by the ferment. 95 The consequence of this reconfiguration of the expressions 'construction' and 'fabrication' was to consider the experiment as an 'event' 96 and 'not a discovery, not an uncovering, not an imposition, not a synthetic a prior judgement, [and] not the actualisation of a potentiality. ${ }^{, 97}$ This brings Latour to the crux of the matter:

\footnotetext{
${ }^{81}$ Latour, Pandora's Hope, 90, 98.

${ }^{82}$ See Latour, Pandora's Hope, $122-127$

${ }^{83}$ Latour, Pandora's Hope, 79.

${ }^{84}$ Latour, Pandora's Hope, 92-112.

${ }^{85}$ Latour, Pandora's Hope, 113

${ }^{86}$ Latour, Pandora's Hope, 114

${ }^{87}$ Latour, Pandora's Hope, 114.

${ }^{88}$ Latour, Pandora's Hope, 115.

${ }^{89}$ Latour, Pandora's Hope, 116-127.

${ }^{90}$ Latour, Pandora's Hope, 122.

${ }^{91}$ See Latour, Pandora's Hope, 122-123.

${ }^{92}$ Latour, Pandora's Hope, 303. See also Harman, Prince of Networks, 11-32.

${ }^{93}$ Latour, Pandora's Hope, 123.

${ }^{94}$ Latour, Pandora's Hope, 123.

${ }^{95}$ Latour, Pandora's Hope, 124.

${ }^{96}$ Noting that Latour prefers 'event' in place of 'discovery' that captures the historicity of the human and non-human components of the experiment and allows ideas about nature, transcendence and causality to be dismissed (Latour, Pandora's Hope, 306). See also Latour, "Do Scientific Objects Have a History," 85-91.

${ }^{97}$ See Latour, Pandora's Hope, 126, 127.
} 
Most philosophy of science since Hume and Kant consists in taking on, evading, hedging, coming back to, recanting, solving, refuting, packing, [and] unpacking this impossible antinomy [paradox]: that on the one hand facts are experimentally made up and never escape from their man-made settings, and on the other hand it is the potential that facts are not made up and that something emerges that is not man-made. ${ }^{98}$

Latour then escapes the prison of claiming the artificiality of the laboratory and "the autonomy of the entity "made up" inside the laboratory walls' by finding two meanings for 'facts. ${ }^{.99}$ As he says:

It is easy to understand why houses and cars and baskets and mugs are at once created and real, but this is of no help in accounting for the mystery of scientific objects. It is not just that they are both made up and real. Rather, it is precisely because they have been artificially made up that they gain a complete autonomy from any sort of production, construction or fabrication. ${ }^{100}$

Latour then points to Pasteur's 'so clever' solution to this 'most puzzling phenomenon. ${ }^{101}$ It is, of course, Pasteur's interpretation of his experiment, using Pasteur's own words quoted by Latour, because 'Whenever a chemist makes a study of these mysterious phenomena and has the good fortune to bring about important development, he will instinctively be inclined to assign their primary cause to a type of reaction consistent with the general results of his own work. ${ }^{102}$ In other words, Pasteur juxtaposes 'Two entirely unrelated epistemologies' - the facts embedded in the theory and the facts judged independently of this theoretical perspective. ${ }^{103}$ The really important point is that Latour says what we see here is a shifting out from one frame of reference into another and that this accounts for the paradox - the ferment experiment is constructed by Pasteur, and yet it is also autonomous; 'Pasteur acts so that the yeast acts alone': ${ }^{104}$

An experiment ... is an action performed by the scientist so that the non-human can be made to appear on its own. The artificiality of the laboratory does not run counter to its validity and truth, its obvious immanence is actually the source of its downright transcendence. How could this apparent miracle be obtained? Through a very simple setup that has baffled observers for a very long time and that Pasteur beautifully illustrates. The experiment creates two planes: one in which the narrator is active, and a second in which the action is delegated to another character, a non-human one. ${ }^{105}$

The construction is happening in Pasteur's frame or plane of reference, and the reality is happening in the ferment's frame or plane of reference-'according to which of these two contradictory features is stressed, the same text becomes either constructivist or realist.' ${ }^{106}$

However, does this just acknowledge that the 'real' was out there all the time, and Pasteur's experiment just discovered what was already there? In other words, 'did ferments exist before Pasteur made them up?' ${ }^{107}$ Latour's answer here is to develop a language that accounts for his conclusion that the answer to the question is clearly: 'No, they did not exist before [Pasteur] came along' because this is 'obvious, natural and even ... commonsensical. ${ }^{108}$ Latour has sided with the (postmodernist) relativism of the Science Wars, except Latour claims that 'realistic realism' is a qualification of the postmodernist relativism. ${ }^{109}$ The important point here is to clearly understand that Latour is using the terminology 'substance' and 'institution' in a very specific way:

What Pasteur made clear for us ... is that we slowly moved from a series of attributes to a substance. The ferment began as attributes and ended up being a substance, a thing with clear limits, with a name, with obduracy, which was more than the sum of its parts. The word 'substance' does not designate what 'remains beneath', impervious to history, but what gathers together a multiplicity of agents into a stable and coherent whole. A substance is more like the thread that holds the pearls of a necklace

\footnotetext{
${ }^{98}$ Latour, Pandora's Hope, 125.

${ }^{99}$ Latour, Pandora's Hope, 127.

${ }^{100}$ Latour, Pandora's Hope, 127.

${ }^{101}$ Latour, Pandora's Hope, 127.

${ }^{102}$ Latour, Pandora's Hope, 128.

${ }^{103}$ Latour, Pandora's Hope, 129.

${ }^{104}$ Latour, Pandora's Hope, 129-130.

105 Latour, Pandora's Hope, 129.

${ }^{106}$ Latour, Pandora's Hope, 130. This also addresses a long-standing controversy for philosophers, historians, and sociologists of science about the 'contexts of discovery' and the 'contexts of justification' distinguishing the dissonance between what scientists do (e.g., make observations, conduct experiments, interpret data and reach conclusions) and what they say they do (e.g., in making presentations and publishing papers and books), with disagreement about understanding and interpreting this controversy (see for example, Schickore, "Doing Science, Writing Science").

${ }^{107}$ Latour, Pandora's Hope, 149.

${ }^{108}$ Latour, Pandora's Hope, 145.

${ }^{109}$ See Stalder, "Beyond Constructivism."
} 
together than the rock bed that remains the same no matter what is built on it. In the same way that accurate reference qualifies a type of smooth and easy circulation, substance is a name that designates the stability of an assemblage. ${ }^{110}$

He then says: "the best word to designate a substance is "institution". ${ }^{111}$ By this, he means:

[S]aying that ferments began to be firmly institutionalized in Lille in 1858 surely cannot pass for anything but a truism. And saying that they - meaning the whole assemblage - were different in Liebig's laboratory in Munich a decade earlier, and that these kinds of differences are what we mean by history, certainly cannot be used as fodder for the Science Wars. ${ }^{112}$

To solve the historicity issue - that ferments existed before Pasteur or that the new thing can happen because the effect was 'already hidden'-Latour talks about the 'spatiotemporal envelope for propositions', ${ }_{113}$ reworking the notion of 'substance' into the notion of 'institution. ${ }^{114}$ It is the 'associations' and 'substitutions' in the ongoing 'event' with reinterpretation: ${ }^{115}$ 'there are two practical meanings ... to the word substance: one is the institution that holds together a vast array of practical setups $\ldots$ and the other is the work of retrofitting that situates a more recent event as what "lies beneath" an older one."116

Latour then says expressly that "Science studies does not say that facts are "socially constructed" ... science studies is not even critical, debunking or provocative', ${ }^{117}$ instead what has happened is that science studies has moved attention from a theory of science to a practice of science. ${ }^{118} \mathrm{He}$ then defines 'practice' as the study of science practices, claiming that this is not about debunking science but rather increasing the number of actors, both human and non-human, that collectively produce science. ${ }^{119}$ The result will be, so Latour assures us, that the more we closely examine a thing as constructed (or fabricated), the more likely we will see it as 'real.' However, has Latour really just entirely avoided the question?

\section{Latour's Answer to the 'Real' Question}

The start of this article framed the purpose as addressing the intriguing question that Latour's hypothesis in Down to Earth presumes that climate change is 'real' and not just an artifice of social construction and that the challenge was to reconcile the Latour in Laboratory Life with the Latour in Down to Earth, as if these were different. Maybe this unfairly and pejoratively frames Latour with the echoes of the Science Wars of the 1990s when objective 'realists' sparred with the 'social constructionists' about reality being fallible and contingent. However, what are we to make of Latour's conclusion to the question in Pandora's Hope, 'Is the ferment real or is it fabricated?'120

In recent years, sociologists examining science have, as a gross generalisation, splintered into a stream of inquiry directed to society in science and another stream directed to science in society. ${ }^{121}$ These generalised groupings have often fought bitter conflicts, ${ }^{122}$ although they do all agree that the practice of science is socially contingent and, as a consequence, ultimately leaves unresolved the question of whether this also means that the results of doing science are also socially contingent (or constructed and fabricated). There does seem, however, to be a consensus that there is some kind of reality — even the most dogmatic sociologists accept this:

What sociologists of science say is that of course the world is real and independent of our observations but that accounts of the world are produced by observers and are therefore relative to their capacities, education, training, etc. It is not the world or its properties but the vocabularies in whose terms we know them that are socially constructed - fashioned by human beingswhich is why our understanding of those properties is continually changing ... It is no contradiction to say that something is socially constructed and also real. ${ }^{123}$

${ }^{110}$ Latour, Pandora's Hope, 151.

${ }^{111}$ Latour, Pandora's Hope, 151.

${ }^{112}$ Latour, Pandora's Hope, 152.

${ }^{113}$ Latour, Pandora's Hope, 153.

${ }^{114}$ Latour, Pandora's Hope, 167.

${ }^{115}$ Latour, Pandora's Hope, 169.

${ }^{116}$ Latour, Pandora's Hope, 170.

${ }^{117}$ Latour, Pandora's Hope, 293, 294.

${ }^{118}$ Latour, Pandora's Hope, 294.

${ }^{119}$ Latour, Pandora's Hope, 309.

${ }^{120}$ Latour, Pandora's Hope, 295.

${ }^{121}$ Sequin, "Bloor, Latour, and the Field," 506-507.

${ }^{122}$ Perhaps the most celebrated being between Bloor and Latour: see Bloor, "Anti-Latour"; Bloor, "Reply to Bruno Latour"; Latour, "For David Bloor ... and Beyond." For another earlier conflict between Harry Collins and Bruno Latour, see: Collins and Yearley, "Epistemological Chicken," 343-368; Callon and Latour, "Don’t Throw the Baby Out with the Bath School," 301-326.

${ }^{123}$ Fish, "Professor Sokal's Bad Joke," 23. 
However, this avoids the issue at the heart of the Science Wars and the central allegation that even if there are socially contingent effects in the early processes of science, in practice, the end result is a reality - any cultural influences are 'refined away, like slag from ore'124 _ and there really is something 'real' out there. The positions are perhaps clarified by a representative statement from the sociologists' constructivist camp:

The central point, which so many fail to grasp, is that society does not simply distort our knowledge of the world, nor does it come between us and reality. Society is enabling: we know reality through it, not in spite of it. Society and culture act like spectacles: through them we collectively see and grasp the world; without them we can see and grasp little or nothing. ${ }^{125}$

This representative statement from the realist scientists' camp also provides clarity:

To put it simply, if scientists are talking about something real, then what they say is either true or false. If it is true, then how can it depend on the social context of the scientist? If it is false, how can it help to liberate us? The choice of scientific question and the method of approach may depend on all sorts of extra-scientific influences, but the correct answer when we find it is what it is because that is the way the world is. ${ }^{126}$

Latour's contribution has been to break down the traditional divide between nature and language (society), give non-humans agency and history, re-conceptualising experiments as 'events', and posit new 'actors' or 'actants' - that a new Pasteur and a new yeast resulted from the encounter between Pasteur and the ferment. This is also where Down to Earth neatly fits into Latour's bigger project; he does accept that climate change is real, it is just that he has a very careful dialectic that does not clearly reject the 'social construction' (or less friendly anti-realism) allegations made about his work and falls towards the side of the sociologists' constructivist camp. This is worth following because it shows that what reality means for Latour is very carefully qualified and falls outside the different camps of the Science Wars' protagonists.

Latour and Woolgar's original title, Laboratory Life: The Social Construction of Scientific Facts (1979), was changed in the later edition removing 'social', so that it became, Laboratory Life: The Construction of Scientific Facts (1986). The term 'social' was removed because Latour and Woolgar considered that it 'no longer has any meaning.' ${ }^{27}$ This was because they consider that 'all interactions are social' and the term referred equally 'to a pen's inscription on graph paper, to the construction of a text and to the gradual elaboration of an amino acid chain.' 128 This clearly makes the point that Latour's project is about the construction of scientific facts where the 'construction' is about the process by which those 'facts' are discovered. ${ }^{129}$ As Latour makes clear in The Promises of Constructivism:

\begin{abstract}
As soon as the word 'construction' succeeds in gaining some of the metaphoric weight of building, builders, workers, architects, masons, cranes and concrete poured into forms held by scaffolds [building a house], it will be clear that it is not the solidity of the resulting construct that's in question, but rather the many heterogeneous ingredients, the long process, the many trades, the subtle coordination necessary to achieve such a result. The result itself is as solid as it gets. ${ }^{130}$
\end{abstract}

Perhaps Latour's most compelling defence of his project was to point out that he was not trying to explain the 'hard facts' of science compared with the 'soft facts' of social science, and uncovering society or nature, but rather 'to understand how science and technology were providing some of the ingredients necessary to account for the very making and the very stability of society. ${ }^{131}$ Put slightly differently, his account was neither merely extending the social explanations to science and technology nor confirming that nature exists out there. ${ }^{132}$

In a dialogue with Fadhila Mazanderani and responding to the notion that Latour must now 'defend science against climate skeptics and others', Latour rejects the claim that he was 'attacking science', saying he was only ever 'just describing what you [scientists] were doing. ${ }^{133}$ More recently, with the impending publication of Down to Earth, Latour was interviewed in the New York Times Magazine under the arresting title, Bruno Latour, the Post-Truth Philosopher, Mounts a Defense of Science. ${ }^{134}$ Latour clearly does not resile from scientific facts being constructed:

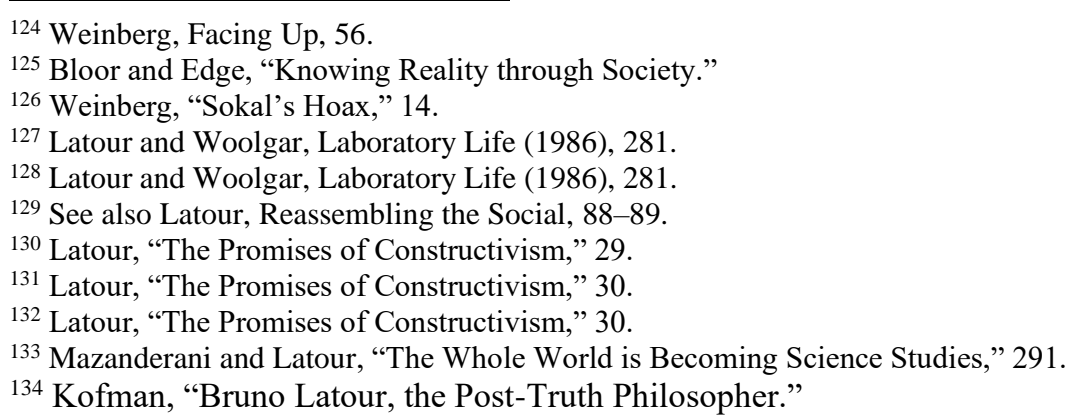


But Latour believes that if the climate skeptics and other junk scientists have made anything clear, it's that the traditional image of facts was never sustainable to begin with. 'The way I see it, I was doing the same thing and saying the same thing', he told me, removing his glasses. 'Then the situation changed.' If anything, our current post-truth moment is less a product of Latour's ideas than a validation of them. In the way that a person notices her body only once something goes wrong with it, we are becoming conscious of the role that Latourian networks play in producing and sustaining knowledge only now that those networks are under assault. ${ }^{135}$

This view was succinctly explained while quoting from Down to Earth in the same New York Times Magazine interview:

What journalists, scientists and other experts fail to grasp, Latour argues, is that 'facts remain robust only when they are supported by a common culture, by institutions that can be trusted, by a more or less decent public life, by more or less reliable media. ${ }^{[136]}$ With the rise of alternative facts, it has become clear that whether or not a statement is believed depends far less on its veracity than on the conditions of its 'construction' - that is, who is making it, to whom it's being addressed and from which institutions it emerges and is made visible. A greater understanding of the circumstances out of which misinformation arises and the communities in which it takes root, Latour contends, will better equip us to combat it. ${ }^{137}$

More recently, in an interview in Science directly addressing the same issue in the context of climate change denial:

Q: How do you explain the rise of antiscientific thinking and 'alternative facts'?

A: To have common facts, you need a common reality. This needs to be instituted in church, classes, decent journalism, peer review ... It is not about post-truth, it is about the fact that large groups of people are living in a different world with different realities, where the climate is not changing ... Science has never been immune to political bias. On issues with huge policy implications, you cannot produce unbiased data. That does not mean you cannot produce good science, but scientists should explicitly state their interests, their values, and what sort of proof will make them change their mind. ${ }^{138}$

These quotations show that Latour does indeed have a view about reality that is at odds with the realist scientists in the Science Wars and that the relativism so abhorrent to scientists is still present in Latour's perspectives. His position is very clear that facts, whether they are scientific or otherwise, are constructed (or fabricated) and do not exist independent of human reality. For Latour, 'The question was never to get away from facts but closer to them, not fighting empiricism but, on the contrary, renewing empiricism. ${ }^{139}$ By this Latour means that facts are an admixture of society (e.g., language, laboratories and funding) and the hard physical reality of the thing (resists), and the more complex this admixture, the more rigorous the reality (more stable).

Recall that in Down to Earth, Latour was addressing, in part, the 'systematic effort to deny the existence of climate change. ${ }^{140}$ Here Latour decries the 'usual epistemology' because this makes us "prisoners of a conception of "nature" that is impossible to politicise' because it adopts the traditional ideal of a reality out there - what Latour calls 'an appeal to the objective laws of nature that cannot be questioned. ${ }^{141}$ Latour also laments that the alternative is not possible, "opposing "scientific rationality" by inventing a more intimate, more subjective, more rooted, more global - more "ecological" as it were — way of capturing our ties to "nature" because this is accepting the traditional ideal of 'nature' without the "contribution of positive knowledge.' 142 Latour's resolution:

We need to be able to count on the full power of the sciences, but without the ideology of 'nature' that has been attached to power. We have to be materialist and rational, but we have to shift these qualities onto the right grounds. ${ }^{143}$

Latour's position is (apparently) clear and Down to Earth accepts that climate change is 'real', albeit constructed (or fabricated), and that the treatment of the 'real' question in Laboratory Life and Down to Earth are consistent. There is, however, a very specific meaning that Latour imposes on the 'real' that requires a broader review of his works to understand his place on the spectrum from realist to relativist. Starting with Science in Action, Latour defines his reality:

${ }^{135}$ Kofman, "Bruno Latour, the Post-Truth Philosopher."

${ }^{136}$ Latour, Down to Earth, 23.

${ }^{137}$ Kofman, "Bruno Latour, the Post-Truth Philosopher."

138 de Vrieze, "Bruno Latour, A Veteran of the Science Wars."

${ }^{139}$ Latour, "Why Has Critique Run Out of Steam," 231.

${ }^{140}$ Latour, Down to Earth, 1.

${ }^{141}$ Latour, Down to Earth, 65.

${ }^{142}$ Latour, Down to Earth, 65

${ }^{143}$ Latour, Down to Earth, 65. 
Laboratories are now powerful enough to define reality. To make sure that our travel through technoscience is not stifled by complicated definitions of reality, we need a simple and sturdy one able to withstand the journey: reality as the Latin word res indicates, is what resists. What does it resist? Trails of strength. If, in a given situation, no dissenter is able to modify the shape of a new object, then that's it, it is reality, at least for as long as the trials of strength are not modified. ${ }^{144}$

In understanding what resists, Latour applies a pragmatic methodology 'follow[ing] the actors themselves. ${ }^{145}$ The result is that, and this is accepting Francisco Salinas insightful analysis, it is Latour's notion of the circulating reference ${ }^{146}$ 'where every entity has the same potential as others to exist and mobilise allies toward the definition of reality. ${ }^{147}$ It is the transformation from nature to word and Latour's pragmatism that sustains the 'real internal world': ${ }^{148}$

[F]or him [Latour], language and reality operate within the same ontological plane where scientists - with the help of invariant forms - can let material things translate into different supports, without letting them become something radically different than what they were before. ${ }^{149}$

It is the circulating reference that maintains the absence of a gap between nature and words, but this can only be sustained where the institution of science is kept functioning, and the gaps between the words and nature can be retraced (so as not 'to interrupt its expansion at either end, to stop providing for it, to suspend its funding or to break it at any other point'). ${ }^{150}$ The key point here is that, for Latour, 'science provides the circulating references that travel within reality' ${ }^{151}$ and it is the alliances (networks) between the various human and non-human actors (or actants) ${ }^{152}$ that sustain knowledge with scientific value for the scientific community - 'elements in existence confront and form alliances with each other in order to keep being real., 153 To understand Latour's reality, however, we need to broaden our lens to what he calls 'modes of existence' that account for the modern divide between the natural world and the social world in which the reference circulates. ${ }^{154}$

Put simply, Latour asserts that we have never been Modern because there has never been an actual separation between nature and culture. ${ }^{155}$ This begs the question, if the two distinct domains of nature and culture do not exist (hence modernity), then what does exist? Latour's answer is what he calls 'modes of existence.' Essentially, we Moderns (thinking of the well-educated, and particularly those in rich countries_-'Occidentals' $)^{156}$ hold the idea of the 'material world' as the example of 'reality' that we often describe in dichotomies like subject/object, nature/culture, concrete/abstract and fact/value. ${ }^{157}$ Latour's point is that the Moderns then format their world according to these dichotomies, separating nature and culture from each other so that there is actually a difference between stated beliefs and actual practices-we construct a world of 'humans, divinities and nonhumans', but we do not 'inhabit a world of signs or symbols arbitrarily imposed on an external Nature. ${ }^{158}$ The 'modes of existence' are Latour's answer, set out in An Inquiry into Modes of Existence, to the duality he sees, which comprise the heterogeneous connections from the diversity of associations and values of Moderns. ${ }^{159} \mathrm{He}$ identifies the Moderns' actual practices in 15 different ways of human activity, such as science, law and religion. ${ }^{160}$ As such, 'modes of existence' are the different values, realities, languages, of each of the different activity groupings. ${ }^{161}$ This helps us to understand how, for our purposes, we understand science as a 'mode of existence' as a way of making sense of our world. Of course, there are at least 15 'modes of existence', and 15 ways of making sense, of a circulating reference.

\footnotetext{
${ }^{144}$ Latour, The Pasteurization of France, 93.

${ }^{145}$ Latour, Reassembling the Social, 12.

146 Illustrated by Latour in his following the soil sampling between savanna and forest in Latour, Pandora's Hope, 24-79.

${ }^{147}$ Salinas, "Bruno Latour's Pragmatic Realism," 12. See also Watson, "Latour's More Realistic Realism"; Harman, Prince of Networks, 7379.

${ }^{148}$ Latour, Pandora's Hope, 58.

${ }^{149}$ Salinas, "Bruno Latour's Pragmatic Realism," 14.

${ }^{150}$ Latour, Pandora's Hope, 76.

${ }^{151}$ Salinas, "Bruno Latour's Pragmatic Realism," 15.

${ }^{152}$ Latour, Pandora's Hope, 303.

${ }^{153}$ Salinas, "Bruno Latour's Pragmatic Realism," 15.

${ }^{154}$ See Salinas, "Bruno Latour's Pragmatic Realism," 17-18.

${ }^{155}$ Latour, We Have Never Been Modern, 11.

${ }^{156}$ Latour, An Inquiry into Modes of Existence, 16.

${ }^{157}$ Latour, An Inquiry into Modes of Existence, 146-147.

${ }^{158}$ Latour, We Have Never Been Modern, 106.

${ }^{159}$ Latour, An Inquiry into Modes of Existence, 42.

${ }^{160}$ See Latour, An Inquiry into Modes of Existence, 488-489.

${ }^{161}$ Latour, An Inquiry into Modes of Existence, 139.
} 


\section{Is it Real-ly about Truth Claims?}

The 'real' in Laboratory Life was a construction of facts; Latour has maintained this position refined through his analysis of the forest/savanna fringe in Pandora's Hope revealing the hidden 'rupture between things and signs', ${ }^{162}$ and through Pasteur and the ferment, again in Pandora's Hope (and The Pasteurization of France), revealing the 'shifting out' from Pasteur's plane to the ferment's plane. ${ }^{163} \mathrm{We}$ then saw that, in An Inquiry into Modes of Existence, in making sense of the circulating reference we (Moderns) required a 'mode of existence' to make sense of that knot of associations, and it is this that is the 'real' in Latour's cosmology. In short, 'science provides the circulating references that travel within reality' 164 and the 'modes of existence' then establish the context for making sense (e.g., religious, legal, scientific) so that 'different modes of existence (not just a scientific approach to reality) assemble within a cosmological arrangement knotted together by their own relations. ${ }^{165}$ For Latour's more middle-ground approach, 'truth and reality do exist, but not as pure ideationally or philosophically distinguishable entities. Truth and reality are the cries of a strong coalition and a practically successful social construction.' ${ }^{166}$ Another way to reveal Latour's real is to approach from the context of the Science Wars.

The Science Wars were essentially about a conflict between an 'irreverent metaphysics and the rage against reason' and a 'scientific metaphysics and an Enlightenment faith in reason. ${ }^{167}$ While Latour and others might reject this conflict, ${ }^{168}$ he was and remains to be (the difference between intentions and the effects of his work) ${ }^{169}$ a key protagonist in the constructivist ${ }^{170}$ undermining of realist science claims about reality — in the language of one rejecting this conflict, 'Climate skeptics, then, are simply correct when they point to such repressive mystifications of Science': ${ }^{171}$

The Scientist as a shaman: by inscribing and engraving, a thing is turned into an object, but is then presented as a terrifying deterrent totem to end disagreement, to end debate and argument, because what has just happened appears as something mysteriously everlasting, eternal, universal. ${ }^{172}$

This leaves the central question of the Science Wars unresolved. Realist scientists still consider that there is a real out there'if we ever discover intelligent creatures on some distant planet and translate their scientific works, we will find that we and they have discovered the same laws.' ${ }^{173}$ Latour would say, this is real if the knot of associations between the human and nonhuman actants survives or resists tests of strength to have a knowledge value among scientists (a circulating reference) and that scientists can make sense of that knowledge according to their ontology ('mode of existence'). ${ }^{174}$ For realist scientists, reality is not dependent on knotted associations, modes or existence, or anything other than whether something is true or false. ${ }^{175}$ Therefore, while Latour might say, as he does, that climate change is real, he does so in the context that 'facts remain robust only when they are supported by a common culture, by institutions that can be trusted, by a more or less decent public life, by more or less reliable media.' 176 Therefore, he is only sometimes talking about the same reality as realist scientists, for whom climate change is real because it is true independent of common cultures and trusted institutions. While the social scientists

162 Latour, Pandora's Hope, 56.

163 Latour, Pandora's Hope, 130.

164 Salinas, "Bruno Latour's Pragmatic Realism," 15.

165 Salinas, "Bruno Latour's Pragmatic Realism," 17.

166 Ward, "In the Shadow of the Deconstructed Metanarratives," 74.

${ }^{167}$ Hacking, The Social Construction of What, 62.

168 See de Vrieze, "Bruno Latour, A Veteran of the Science Wars," where Latour states:

'Nothing that happened during the '90s deserves the name "war"... We're in a totally different situation now [2017]. We are indeed at war. This war is run by a mix of big corporations and some scientists who deny climate change. They have a strong interest in the issue and a large influence on the population.'

169 Even Latour accepts that this is possible:

'I myself have spent some time in the past trying to show "the lack of scientific certainty" inherent in the construction of facts. I too made it a "primary issue". But I did not exactly aim at fooling the public by obscuring the certainty of a closed argument—or did I?' (Latour, "Why Has Critique Run Out of Steam," 227).

Although maybe not: see Latour, "Biography of an Inquiry," 292.

170 Noting that Latour's is a more realistic realism: see Salinas, "Bruno Latour's Pragmatic Realism," 19.

171 van Eeden, "Materializing Discourse Analysis with James, Schmitt and Latour," 14.

172 van Eeden, "Materializing Discourse Analysis with James, Schmitt and Latour," 14.

173 Weinberg, "Sokal's Hoax," 14.

174 Put slightly differently:

'If there is no controversy among scientists as to the status of fact, then it is useless to go on talking about interpretation, representation, a biased or distorted world-view, weak and fragile pictures of the world, [and] unfaithful spokesmen. Nature talks straight, facts are facts. Full stop. There is nothing to add and nothing to subtract' (Latour, The Pasteurization of France, 100).

175 See Weinberg, "Sokal's Hoax," 14.

${ }^{176}$ Latour, Down to Earth, 23. 
might consider this 'the touching naïveté of natural scientists', ${ }^{177}$ the analysis in this article reaches the position that Latour does not really add to the 'real' debate beyond falling on the relativists side as a moderate between the extreme science realists (facts are either true or false) versus extreme social relativists (facts are a social construction). This begs the question, what are Latour's 'real intentions'? ${ }^{178}$ This is another fascinating and productive detour worth retracing.

Latour completed his doctoral work on a biblical exegesis considering the truth conditions of the Gospel. ${ }^{179}$ With this background, he recounts:

[W] hen I entered the biological laboratory in California [Salk Institute], where I began my first serious ethnographic field study, I was primed to detect its exegetic dimension in the immense complexity of scientific practice. Hence, my fascination for the literary aspects of science, for the visualizing tools, for the collective work of interpretation around barely distinguishable traces, for what I called inscriptions. Here too, exactly as in the work of biblical exegesis, truth could be obtained not by decreasing the number of intermediary steps, but by increasing the number of mediations. ${ }^{180}$

The insights from his doctoral work and his work in the Republic of Côte d'Ivoire, followed by the laboratory experience at the Salk Institute, led Latour to conclude that he "could detach [himself] from the dispute between "knowledge" and "belief" and replace those two most confusing terms with two sets of empirically graspable chains of translations [what Latour called "immutable mobiles" $]^{[181]}$ that were spreading along two different regimes. ${ }^{182}$ For Latour, these were 'a comparative method for studying various types of truth production that did not rely on the usual notions (the supernatural and the natural, for instance)' and engaged the elements of 'networks of translations' and 'the mode or the regime in which they were made to spread.' ${ }^{183}$ Latour laments this 'bitterly', and it came as a 'great surprise': ${ }^{184}$

[W] hat I had taken as a rather innocent method to study the truth conditions of science (exactly as I had adopted the exegetic method to study the different truth conditions of religious enunciation), was immediately taken by my readers as a debunking of the claims of scientific reason to objectivity. ${ }^{185}$

For Latour, the realist versus relativist controversies were 'a complete red herring' and a 'complete disconnect between what I thought I was doing (a realist description of the scientific network's ability to produce objectivity) and what I was accused of doing (a debunking of science's claim to reach the natural objective world of matters of fact). ${ }^{186}$ From this, Latour gained the insight, founded in the works of Isabelle Stengers, Alfred North Whitehead and William James, that the distinction between matter and nature in the 'modernist idiom' was complicated by the 'historically contingent amalgam' of matter as 'the way we know (which is generated by the reference chain of science)' and 'the way entities reproduce themselves.' ${ }^{187}$ This revealed an 'entrenched prejudice' so that 'the sacrosanct distinction between facts and values' rested on 'primary qualities (the stuff out of which the objective world is made)' and 'secondary qualities (the subjective values that the mind adds to it- “psychic additions" is Whitehead's term for it). ${ }^{188}$ For Latour:

[This] is not another failed attempt to add some 'spiritual' dimension to a 'reductionist and mechanical world view', but, on the contrary, it is a way to subtract from the ill-conceived bags of matter and of nature a spurious spirituality borrowed for scientistic and political reasons (as I soon learned by getting into the politics of nature). To usher ourselves out of nature, is the only way to put an end to the modernist parenthesis while avoiding the negative and somewhat desperate solution of postmodernism. ${ }^{189}$

This reveals that Latour's project has been about truth claims and rejecting 'the modernist invention of matters of fact.' ${ }^{\prime 90}$ As he says, we have never been Modern. Latour is just assessing truth claims — revisiting Laboratory Life: "Reality" cannot be

177 Collins and Evans, Why Democracies Need Science, 37.

${ }^{178}$ Latour, Coming Out as a Philosopher, 600.

${ }^{179}$ Latour, Coming Out as a Philosopher, 599. See also Tresch, "Another Turn after ANT," 303-304. An intriguing question remains about the role and place of religious belief in Latour's work: see, for example, Gunnar, "Bruno Latour's Anthropology of the Moderns."

${ }^{180}$ Latour, Coming Out as a Philosopher, 601.

${ }^{181}$ See Latour, Visualisation and Cognition.

${ }^{182}$ Latour, Coming Out as a Philosopher, 601.

${ }^{183}$ Latour, Coming Out as a Philosopher, 601.

${ }^{184}$ Latour, Coming Out as a Philosopher, 601.

${ }^{185}$ Latour, Coming Out as a Philosopher, 601.

${ }^{186}$ Latour, Coming Out as a Philosopher, 602.

${ }^{187}$ Latour, Coming Out as a Philosopher, 604.

${ }^{188}$ Latour, Coming Out as a Philosopher, 604.

${ }^{189}$ Latour, Coming Out as a Philosopher, 604.

${ }^{190}$ Latour, Coming Out as a Philosopher, 606. 
used to explain why a statement becomes a fact since it is only after it has become a fact that the effect of reality is obtained.' ${ }^{191}$ He says again and in more recent times: 'Truth production in science, religion, law, politics, technology, economics, and so on, is what I have been studying over the years', and all for 'my program to advance toward an anthropology of modernity.' 192 Consequently, 'facts are thoroughly understandable in terms of their social construction.' 193 This is because, for Latour in his cosmology, this is not a rejection of the existence of reality, but rather this is about the merits of truth claims; he doesn't say facts and reality do not exist as his point is that 'out-there-ness' is 'the consequence of scientific work rather than its cause.' 194 The temporality reinforces this cosmology apparent even at the time of Laboratory Life:

\begin{abstract}
By considering TRF in January 1968, it would be easy to show that TRF is a contingent social construction, and moreover, that scientists themselves are relativists in that they are very aware of the possibility of their constructing a reality which could be an artefact. On the other hand, analysis in January 1970 would reveal TRF as an object of nature which had been discovered by scientists, who, in the meantime, had metamorphosed into hardened realists. Once the controversy has settled, reality is taken to be the cause of this settlement; but while controversy is still raging, reality is the consequence of debate, following each twist and turn in the controversy as if it were the shadow of scientific endeavour. ${ }^{195}$
\end{abstract}

Latour and Woolgar, in Laboratory Life, then carefully qualify this statement to limit the TRF reality by asserting that settling the controversy that was the contingent social construction was only 'a belief and a claim' and not proof because the settled contingent social construction is only ever in the context of its construction (and in the case of TRF this was the laboratory). ${ }^{196}$ This perhaps confirms that Latour is, and was only ever, assessing the truth claims (that a statement accords with reality) and not reality claims (that the thing exists as a fact), in the same way he has been for theological exegeses, biology laboratories, ${ }^{197}$ industrial laboratories ${ }^{198}$ and making law, ${ }^{199}$ and with each mode of existence having its own truth conditions. ${ }^{200}$ He even says:

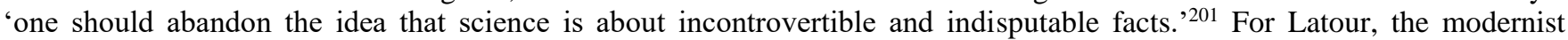
settlement of ontological assumptions about the reality of nature and society need to be jettisoned. In its place, truth is based on credibility, and this is determined by the network of associations and translations, the more associations, the more credible the truth claim. As Latour outlines in Pandora's Hope, Pouchet's spontaneous generation became less and less real as Pasteur's germ theory became more and more real, and this was because Pasteur's germ theory gained more and more associations (e.g., machines, gestures, textbooks, institutions and taxonomies), while Pouchet's spontaneous generation shed associations. ${ }^{202}$ This brings us back to the historicity issue and Latour's provocative question, 'Did ferments exist before Pasteur?' ${ }^{203}$ For Latour, the answer is no, because he has recrafted matters of fact:

MATTER OF FACT: The general drift of science studies is to make matters of fact, as in common parlance, what is already present in the world, but a rather later outcome of a long process of negotiation and institutionalisation. This does not limit their certainty but, on the contrary, provides all that is necessary for matters of fact to become indisputable and obvious. To be indisputable is the end point, not the beginning as in the empiricist tradition. ${ }^{204}$

The 'torsion test' 205 between Pasteur and Pouchet over spontaneous generation demonstrates for Latour that 'when a phenomenon "definitely" exists this does not mean that it exists forever, or independently of all practice or discipline' but rather, 'that it has been entrenched in a costly and massive institution that has to be monitored and protected with great care."206 Here, Latour is dealing with what he calls 'relative existence', ${ }^{207}$ by which he means 'existence not as an all-or-nothing concept but as a gradient' that both 'allows for finer differentiations than the demarcation between existence and non-existence' and 'to

\footnotetext{
${ }^{191}$ Latour and Woolgar, Laboratory Life (1986), 180.

${ }^{192}$ Latour, "Thou Shalt Not Freeze-Frame," 28.

${ }^{193}$ Latour and Woolgar, Laboratory Life (1986), 107.

${ }^{194}$ Latour and Woolgar, Laboratory Life (1986), 180-182.

${ }^{195}$ Latour and Woolgar, Laboratory Life (1986), 182.

${ }^{196}$ Latour and Woolgar, Laboratory Life (1986), 182-183.

${ }^{197}$ Latour and Woolgar, Laboratory Life (1986).

${ }^{198}$ Latour, Aramis.

${ }^{199}$ Latour, The Making of Law.

${ }^{200}$ Latour, Coming Out as a Philosopher, 607.

${ }^{201}$ Latour, Telling Friend from Foe in the Time of the Anthropocene, 148.

${ }^{202}$ Latour, Pandora's Hope, 158-159.

${ }^{203}$ Latour, Pandora's Hope, 147, 152, 169.

${ }^{204}$ Latour, Pandora's Hope, 307.

${ }^{205}$ Latour, Pandora's Hope, 153.

${ }^{206}$ Latour, Pandora's Hope, 155-156.

${ }^{207}$ Latour, Pandora's Hope, 156. For another example where Latour deals with whether Ramses II's cause of death was tuberculosis that was invented, made up or socially constructed by Robert Koch's bacillus in 1882 and traced back in its modern form to 1819 see Latour, "On the Partial Existence of Existing."
} 
avoid using the notion of belief. ${ }^{208}$ This also makes space for the non-humans and expands history as the preserve of humans and non-humans. ${ }^{209}$ The result for Latour is that existence happens on a gradient and reality is, as set out above, just more real when gaining associations (Pasteur and germ theory) and less real when shedding associations (Pouchet and spontaneous generation). ${ }^{210}$ For Latour, this means that 'existence and reality are extracted, not from a one-to-one correspondence between an isolated statement and a state of affairs, but from the unique signature drawn by associations and substitutions through the conceptual space. ${ }^{211}$ To remain in existence and reality then requires work because we can only say Pasteur was right and Pouchet wrong 'on the condition that we render very clearly and precisely the institutional mechanisms that are still at work to maintain the asymmetry between the two positions.' 212 Therefore, how 'did ferments exist before Pasteur?' ${ }^{213}$ For Latour, the obvious answer is because Pasteur 'reinterpreted the practices of the past in a new light' so that Pasteur could now do in the laboratory what had been happening all along. ${ }^{214}$ In other words, 'What Pasteur did was to produce in 1864 a new version of the years 1863, 1862, [and] 1861, which now included a new element: "microbes fought unwittingly by faulty and haphazard practices". ${ }^{215}$ Returning to 1863,1862 and 1861 requires intervention and construction, with the effect of altering the year and constructing a new version of the same year now, and 'After 1864 airborne germs were there all along. ${ }^{216}$

\begin{abstract}
Why can't we say that Pasteur was right and Pouchet was wrong? Well, we can say it, but only on the condition that we render very clearly and precisely the institutional mechanisms that are still at work to maintain the asymmetry between the two positions. The solution to this problem is to formulate the question in the following way: In whose world are we now living, that of Pasteur or that of Pouchet? I don't know about you, but for my part, I live inside the Pasteurian network, every time I eat pasteurized yoghurt, drink pasteurized milk, or swallow antibiotics..$^{217}$
\end{abstract}

Therefore, when Latour accepts climate change is real in Down to Earth, he is accepting that the current associations in favour of climate change being true (e.g., scientists, machines, gestures, textbooks, institutions and journals) are more robust-so more real-than the associations asserting something different. This also means that Latour accepts climate change will cease being real (true) if and when those associations are shed. Therefore, this is real-ly addressing the truth claims about climate change and not the realist versus relativist contest about whether climate change $i$ s real. This is because 'Nothing exists but actants, and all of them are utterly concrete', ${ }^{218}$ and climate change is real (or rather true) for Latour because of the actants' more robust associations compared to those of the (current) alternative(s).

\title{
Conclusions
}

Latour's project has been to resist ontological reductionism and posit a world of human and non-human assemblages that determine meaning and structure. This is, in Latour's terms, a social construction and, as this article documents, is best characterised as being about truth claims and not the 'real.' Latour elegantly avoids the complex, and ultimately unrewarding and unhelpful epistemological questions that have plagued the Science Wars-things exist independently of us versus things are constructed by the mind. ${ }^{219}$ Therefore, it is unsurprising that Latour's reaction to being 'taken by [his] readers as ... debunking ... the claims of scientific reason to objectivity' was a feeling of 'great surprise' ${ }^{220}$ because he did not ever consider himself to be addressing those questions. However, perhaps his project that opened the real to 'Golden Mountains', 'phlogiston', 'unicorns', 'chimeras' and 'spontaneous generation'221 (and all those other fantastical and conspiratorial irritations for realist scientists) would inevitably elicit that reader response? As Latour says, this criticism overlooks his careful definition of existence and reality that rejects the one-to-one correspondence between nature and language (society) and instead looks to associations. ${ }^{222}$ For Latour, it is all about actants locked in trials of strength, and for the Latour in Down to Earth, those presently

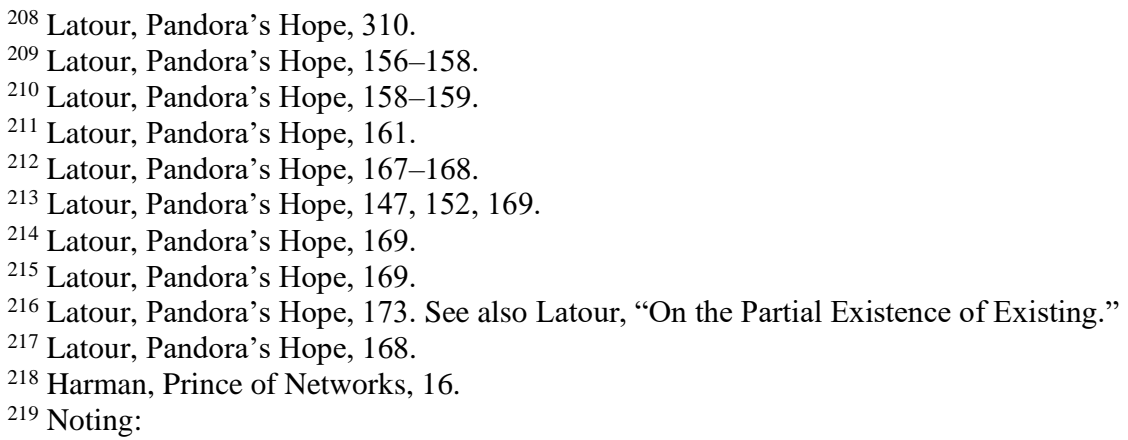

' $[\mathrm{T}]$ he dispute eventually played itself out with no clear resolution ... The popularity of social constructivism, as a particular theoretical perspective, waned not because it was heretical, but because, in the sectors of the academy where it was tolerated, it was not heretical enough to suit proponents of a more thorough and relentless politicization of scientific knowledge' (Lynch, "Social Constructivism in Science and Technology Studies," 110,111).

${ }^{220}$ Latour, Coming Out as a Philosopher, 601.

${ }^{221}$ Latour, Pandora's Hope, 161.

${ }^{222}$ Latour, Pandora's Hope, 161. 
strong actants for climate change have the superior associations. Following Latour's reasoning, however, this could real-ly easily change if, like the Pouchet's spontaneous generation that became less and less real as Pasteur's germ theory became more and more real, ${ }^{223}$ the climate change actant(s) shed their associations.

\section{Bibliography}

Bloor, David. “Anti-Latour.” Studies in History and Philosophy of Science 30, no 1 (1999): 81-112.

Bloor, David. "Reply to Bruno Latour." Studies in History and Philosophy of Science 30, no 1 (1999): 131-138.

Bloor, David and David Edge. "Knowing Reality through Society." Physics World 11, no 3 (1999): 23.

Brown, James Robert. Who Rules in Science? An Opinionated Guide to the Wars. Boston: Harvard University Press, 2001.

Callon, Michel and Bruno Latour. "Don't Throw the Baby Out with the Bath School." In Science as Practice and Culture, edited by Andrew Pickering, 343-68. Chicago: University of Chicago Press, 1992.

Collins, Harry and Robert Evans. Why Democracies Need Science. Cambridge: Polity Press, 2017.

Collins, Harry and Steven Yearley. "Epistemological Chicken." In Science as Practice and Culture, edited by Andrew Pickering, 301-26. Chicago: University of Chicago Press, 1992.

Feyerabend, Paul. Against Method. London: New Left Books, 1975.

Foucault, Michel. Discipline and Punish: The Birth of the Prison. New York: Pantheon Books, 1977.

Gieryn, Thomas. The Cultural Boundaries of Science: Credibility on the Line. Chicago: University of Chicago Press, 1999.

Gross, Paul and Norman Levitt. Higher Superstition: The Academic Left and Its Quarrels with Science. Baltimore: John Hopkins University Press, 1994.

Hacking, Ian and Jan Hacking. The Social Construction of What? Boston: Harvard University Press, 1999.

Harman, Graham. Prince of Networks: Bruno Latour and Metaphysics. Melbourne: Repress, 2009.

Irigaray, Luce. "Sujet de la Science, Sujet Sexue?" In Sens et Place des Connaissances dans la Societe, Volume 3. Paris: Centre National de Reserche Scientifique, 1987.

Kristeva, Julia. Horror: An Essay on Abjection. New York: Columbia University Press, 1982.

Kuhn, Thomas. The Structure of Scientific Revolutions. Chicago: University of Chicago Press, 1970.

Labinger, Jay and Harry Collins. The One Culture? A Conversation about Science. Chicago: University of Chicago Press, 2010.

Latour, Bruno. "Visualisation and Cognition: Drawing Things Together." In Knowledge and Society Studies in the Sociology of Culture Past and Present, edited by Elizabeth Long and Henrika Kuklick, Volume 6, 1-40. Greenwish: Jai Press, 1986.

Latour, Bruno. Science in Action. Boston: Harvard University Press, 1987.

Latour, Bruno. The Pasteurization of France. Boston: Harvard University Press, 1988.

Latour, Bruno. “A Relativistic Account of Einstein's Relativity.” Social Studies of Science 18, no 1 (1988): 3-44. https://doi.org/10.1177\%2F030631288018001001

Latour, Bruno. We Have Never Been Modern. Boston: Harvard University Press, 1993.

Latour, Bruno. "The 'Pédolil' of Boa Vista: A Photo-Philosophical Montage.” Common Knowledge 4 (Spring 1995): $144-87$.

Latour, Bruno. Aramis or the Love of Technology. Boston: Harvard University Press, 1996.

Latour, Bruno. "Do Scientific Objects Have a History? Pasteur and Whitehead in a Bath of Lactic Acid." Common Knowledge 5, no 1 (1996): 76-91.

Latour, Bruno. "For David Bloor ... and Beyond: A Reply to David Bloor's 'Anti-Latour'." Studies in History and Philosophy of Science 30, no 1 (1999): 113-30.

Latour, Bruno. Pandora's Hope: Essays on the Reality of Science Studies. Boston: Harvard University Press, 1999.

Latour, Bruno. The Making of Law: An Ethnography of the Conseil D'Etat. Translated by Marina Brilman and Alain Pottage. London: Polity Press, 1999.

Latour, Bruno. "On the Partial Existence of Existing and Non-Existing Objects." In Biographies of Scientific Objects, edited by Lorraine Daston, 247-69. Chicago: Chicago University Press, 2000.

Latour, Bruno. “The Promises of Constructivism.” In Chasing Technology: Matrix of Materiality, edited by Don Ihde and Evan Selinger, 27-46. Bloomington: Indiana University Press, 2003.

Latour, Bruno. "Why Has Critique Run Out of Steam? From Matters of Fact to Matters of Concern." Critical Inquiry 30 (Winter 2004): 225-48. https://doi.org/10.1086/421123

Latour, Bruno. Reassembling the Social: An Introduction to Actor-Network-Theory. Oxford: Oxford University Press, 2005.

Latour, Bruno. "Thou Shalt Not Freeze-Frame: Or How Not to Misunderstand the Science and Religion Debate.” In Science, Religion and Human Experience, edited by James Proctor, 27-48. New York: Oxford University Press, 2005.

${ }^{223}$ Latour, Pandora's Hope, 158-159. 
Latour, Bruno. “Coming Out as a Philosopher.” Social Studies of Science 40, no 1 (2010): 599-608. https://doi.org/10.1177\%2F0306312710367697

Latour, Bruno. "Biography of an Investigation: On a Book about Modes of Existence." Social Studies of Science 43, no 2 (2013): 287-301. https://doi.org/10.1177\%2F0306312712470751

Latour, Bruno. An Inquiry into Modes of Existence. Boston: Harvard University Press, 2013.

Latour, Bruno. "Telling Friend from Foe in the Time of the Anthropocene." In The Anthropocene and the Global Environmental Crisis, edited by Clive Hamilton, Christophe Bonneuil, and François Gemenne, 145-55. New York: Routledge, 2015.

Latour, Bruno. Down to Earth: Politics in the New Climatic Regime. Translated by Catherine Porter. Cambridge: Polity Press, 2018

Latour, Bruno and Steve Woolgar. Laboratory Life: The Social Construction of Scientific Facts. Beverly Hills: SAGE Publications, 1979.

Latour, Bruno and Steve Woolgar. Laboratory Life: The Construction of Scientific Facts. Princeton: Princeton University Press, 1986.

Lynch, Michael. "Social Constructivism in Science and Technology Studies.” Human Studies, 39 (2016): 101-12. https://doi.org/10.1007/s10746-016-9385-5

Lyotard, Jean François. The Postmodern Condition: A Report on Knowledge. Manchester: Manchester University Press, 1979.

Mazanderani, Fadhila and Bruno Latour, "The Whole World is Becoming Science Studies: Fadhila Mazanderani Talks with Bruno Latour." Engaging Science, Technology, and Society 4 (2018): 284-302. https://doi.org/10.17351/ests2018.237

Mermin, David. "What's Wrong with This Reading." Physics Today 50, no 10 (October 1997): 11-13.

Merton, Robert. The Sociology of Science: Theoretical and Empirical Investigations. Chicago: Chicago University Press, 1973.

Otto, Shaw. The War on Science: Who Is Waging It, Why It Matters, What We Can Do about It. Minneapolis: Milkweed Editions, 2016.

Rouse, Joseph. "Feminism and the Social Construction of Scientific Knowledge." In Feminism, Science, and the Philosophy of Science, edited by Lynn Hankinson Nelson and Jack Nelson, Volume 256, 195-215. Boston: Kluwer Academic, 1997.

Salinas, Francisco. "Bruno Latour's Pragmatic Realism: An Ontological Inquiry." Global Discourse 6, no 1-2 (2016): 8-21. http://dx.doi.org/10.1080/23269995.2014.992597

Schickore, Jutta. “Doing Science, Writing Science.” Philosophy of Science 75, no 3 (2008): 323-43. https://doi.org/10.1086/592951

Sequin, Eve. "Bloor, Latour, and the Field." Studies in the History and Philosophy of Science 31, no 3 (June 2000): 503-8. https://doi.org/10.1016/S0039-3681(00)00020-0

Skirbekk, Gunnar. "Bruno Latour's Anthropology of the Moderns: A Reply to Maniglier.” Radical Philosophy 189 (January/February 2015): 45-7.

Segerstråle, Ullica. "Science and Science Studies: Enemies or Allies." In Beyond the Science Wars: The Missing Discourse about Science and Society, edited by Ullica Segerstråle, 1-40. New York: State University of New York Press, 2000.

Smith, Barbara Herrnstein. Belief and Resistance: Dynamics of Contemporary Intellectual Controversy. Boston: Harvard University Press, 1997.

Snow, Charles Percy. The Two Cultures. Cambridge: Cambridge University Press, 1959.

Sokal, Alan and Jean Bricmont. Intellectual Imposters. London: Profile Books, 1998.

Sokal, Alan and Jean Bricmont. Fashionable Nonsense: Postmodern Intellectuals' Abuse of Science. London: Picador, 1999.

Stalder, Felix. "Beyond Constructivism: Towards a Realistic Realism.” Information Society 16, no 3 (2000): $245-47$.

Tresch, John. “Another Turn after ANT: An Interview with Bruno Latour.” Social Studies of Science 43, no 2 (2013): 30213. https://www.researchgate.net/deref/http\%3A\%2F\%2Fdx.doi.org\%2F10.1177\%2F0306312712468362

Turner, Charles. "Travels Without a Donkey: The Adventures of Bruno Latour." History of the Human Sciences 28, no 1 (2015) 118-38. https://doi.org/10.1177\%2F0952695114551654

van Eeden, Pepijn. "Materializing Discourse Analysis with James, Schmitt and Latour." Palgrave Communications 3 (June 2017): 17039 https://doi.org/10.1057/palcomms.2017.39

Walsh, Anthony. Science Wars: Politics, Gender and Race. Rutgers: Transaction Publishers, 2013.

Ward, Steven. "In the Shadow of the Deconstructed Metanarratives: Baudrillard, Latour and the End of Realist Epistemology." History of the Human Sciences 7, no 4 (November 1994): 73-94. https://doi.org/10.1177\%2F095269519400700405

Watson, Matthew. "Latour's More Realistic Realism: A Reply to Salinas.” Global Discourse 6, no 1-2 (2016): 22-5. https://doi.org/10.1080/23269995.2015.1009263

Weinberg, Steven. “Sokal's Hoax.” New York Review of Books XLIII, no 13 (August 1996): 11-5.

Weinberg, Steven. Facing Up: Science and Its Cultural Adversaries. Boston: Harvard University Press, 2001. 
Wheen, Francis. How Mumbo-Jumbo Conquered the World: A Short History of Modern Delusions. London: Fourth Estate, 2004.

\section{News/Magazine articles}

de Vrieze, Jop. “Bruno Latour, A Veteran of the 'Science Wars,' Has a New Mission.” Science, October 10, 2017. https://www.sciencemag.org/news/2017/10/bruno-latour-veteran-science-wars-has-new-mission

Fish, Stanley. "Professor Sokal's Bad Joke.” New York Times, May 21, 1996.

Kofman, Ava. "Bruno Latour, the Post-Truth Philosopher, Mounts a Defense of Science," New York Times Magazine October 25, 2018. https://www.nytimes.com/2018/10/25/magazine/bruno-latour-post-truth-philosopher-science.html 